\title{
FAKTOR YANG BERPERAN DAN DINAMIKA PSIKOLOGIS YANG TERJADI PADA MAHASISWA SAAT MELAKUKAN KECURANGAN AKADEMIK
}

\begin{abstract}
Anna Armeini
Abstract

Academic misconduct performed by the university students is an illegal practise and will give negative effects to the individual as well as the related institution. This research aims at discovering significant factors and psychological dynamics in the university students performing academic misconduct. The research based on the post positivistic paradigm with three students of State University of Jakarta as the objects of the study. Using interview technique in collecting data, the research conducted in the odd semester of 2009/2010 concludes that demographic factor, individual factor, and situational factor are the signifant factors. The academic misconduct performer has a psychological dynamic showing dissonance. The performer believes academic misconduct is inapprorate, but he/ she still keeps doing.
\end{abstract}

Key words: academic misconduct, psychological dynamic, demographic factor, individual factor, situational factor, dissonance.

\section{Abstrak}

Kecurangan akademik adalah tindakan ilegal yang dilakukan untuk mencapai tujuan tertentu. Cepat atau lambat, perilaku kecurangan merugikan individu pelakunya dan institusi pendidikan yang terkait. Penelitian ini bertujuan untuk mengetahui faktor yang berperan sehingga subyek melakukan kecurangan akademik dan dinamika psikologis yang terjadi saat melakukannya. Pendekatan yang digunakan dalam penelitian ini adalah pendekatan kualitatif dengan tiga subjek penelitian yang merupakan mahasiswa Universitas Negeri Jakarta. Metode pengumpulan data dilakukan dengan wawancara. Hasil penelitian yang dilakukan dalam semester ganjil 2009/2010 ini menunjukkan bahwa kecurangan akademik dipengaruhi oleh faktor demografi, faktor individual, dan faktor situasional. Pelaku kecurangan akademik mengalami dinamika psikologis yang menunjukkan terjadinya dissonansi. Pelaku meyakini bahwa tindakan kecurangan akademik salah tetapi tetap melakukannya.

Kata kunci: kecurangan akademik, dinamika psikologis, faktor demografi, faktor individual, faktor situasional, dissonansi

\section{PENDAHULUAN}

Fenomena yang terjadi tentang banyaknya kasus terkait dengan perilaku tidak jujur dalam bidang akademik yang dilakukan oleh mahasiswa cukup memprihatinkan. Perilaku tidak jujur yang sering dilakukan oleh sebagian mahasiswa adalah perilaku curang saat mengerjakan ujian di kelas ataupun saat mengerjakan tugas-tugas akademik lainnya.

Perilaku kecurangan dapat menurunkan kualitas akademik pada individu mahasiswa dan lembaga pendidikan yang terkait. Bahkan jika kondisi ini terjadi maka akan membuat integritas akademik dapat dipertanyakan baik dari sisi mahasiswa secara individu ataupun universitas secara kelembagaan (Anderman \& Murdoch, 2007). Pada akhirnya kualitas dan kuantitas hasil belajar selama di perguruan tinggi menjadi tidak optimal. Selain itu dikhawatirkan mahasiswa akan meneruskan kondisi dan perilaku tersebut di lingkungan tempat bekerja. Menurut Becker et.al. (2006), mahasiswa yang cenderung melakukan ketidakjujuran dalam bidang akademik maka akan cenderung melakukan beragam ketidakjujuran di dunia kerja.

Berdasarkan hal-hal tersebut, penelitian ini bertujuan untuk mengetahui faktor apa saja yang berperan sehingga mahasiswa melakukan kecurangan akademik terutama saat ujian, serta bagaimana dinamika psikologis yang dialami pelakunya.

\section{KAJIAN PUSTAKA}

Kecurangan akademik merupakan perilaku yang mencerminkan ketidakjujuran dalam rangka memperoleh prestasi akademik. Perilaku ini dapat berupa menggunakan kesempatan untuk melihat catatan atau buku pada saat ujian tertulis yang bersifat 
close book, sampai pada perilaku mengutip pendapat atau teori orang lain tanpa menyebutkan sumbernya. Menurut Alhadza (2002), perilaku kecurangan adalah segala perilaku atau trik-trik yang tidak jujur, perilaku tidak terpuji atau perilaku curang yang dilakukan oleh seseorang untuk mencapai keberhasilan dalam menyelesaikan tugas-tugas akademik terutama yang terkait dengan evaluasi atau ujian hasil belajar.

Perilaku kecurangan menyebabkan proses dan hasil asesmen terhadap prestasi akademik menjadi tidak valid (Gomez, 2001, dalam Mason, 2006). Perilaku kecurangan akan semakin cenderung dilakukan jika mahasiwa berada dalam situasi belajar yang menuntut pencapaian maksimal sementara kesempatan untuk hal tersebut sedikit atau peluang yang dimiliki tidak besar (Wolfolk, 2004).

\section{Kecurangan Akademik dalam Perspektif Psikologi}

Kecurangan dalam bidang akademik dapat dilihat dari beragam perspektif psikologi (Anderman, 2007):

\section{Perspektif belajar}

Kecurangan akademik merupakan strategi kognitif yang menggunakan jalan pintas. Mahasiswa yang melakukan kecurangan dapat disebabkan ketidaktahuan bagaimana menggunakan strategi belajar yang efektif atau karena mereka tidak ingin menghabiskan waktu untuk mencoba/menggunakan beberapa jenis strategi belajar.

\section{Perspektif perkembangan}

Kecurangan akademik dapat terjadi dalam porsi kualitas dan kuantitas yang beragam tergantung pada tingkat perkembangan kognitif, sosial, dan moral. Dalam hal ini, umur yang lebih muda/anak-anak lebih sedikit dalam melakukan perilaku kecurangan dibandingkan orang dewasa (Miller, Murdock, Anderman, \& Poindexter, dalam Anderman, 2007). Tuntutan keberhasilan akademik pada usia kanakkanak tidak sebesar tuntutan keberhasilan akademik pada masa perkembangan selanjutnya termasuk masa dewasa. Selain itu, kecurangan akademik cenderung lebih banyak terjadi pada tingkat sekolah menengah dibandingkan tingkat sekolah dasar karena pengajaran yang lebih fokus pada pencapaian peringkat dan kemampuan (Anderman \& Midgley, 2004; Anderman \& Turner, 2004).

\section{Perspektif Motivasi}

Beragam motivasi yang berada di balik timbulnya kecurangan akademik. Sebagian mahasiswa melakukannya karena motivasi eksternal seperti motivasi untuk memperoleh ranking tertentu. Sebagian yang lain melakukan kecurangan karena menjaga 'image' tertentu di antara teman-temannya, atau karena rendahnya self efficacy/keyakinan diri untuk menyelesaikan tugas-tugas akademik.

Menurut Whitley (1998, dalam Clement, 2001) setelah mempelajari 107 penelitian tentang kecurangan akademik (tahun 1970-1996), kecurangan akademik lebih dimotivasi oleh ketakutan untuk mendapatkan nilai buruk dalam ujian atau tugas dalam mata kuliah tertentu dan bukan karena ketidakmampuan akademik.

\section{Jenis-jenis Kecurangan Akademik}

Kecurangan akademik memiliki jenis yang beragam. Berdasarkan pendapat Newstead, FranklyStokes, dan Armsted (1996, dalam Haryanto, 1998), terdapat sekitar dua puluh satu jenis kecurangan akademik yang dibagi menjadi dua kelompok besar, yaitu:

1. Kecurangan akademik dalam situasi ujian di kelas adalah sebagai berikut.

a. Menyalin hasil jawaban dari mahasiswa yang posisinya berdekatan selama ujian tanpa disadari mahasiswa lain tersebut.

b. Membawa bahan yang tidak diijinkan ke dalam ruang ujian (misalnya: contekan).

c. Secara diam-diam memperoleh informasi awal tentang soal ujian.

d. Kolusi yang terencana antara dua atau lebih mahasiswa untuk mengkomunikasikan jawabannya selama ujian berlangsung.

e. Berbohong tentang kondisi medis atau hal lain untuk memperoleh pertimbangan khusus dari penguji.

f. Mengikuti ujian atas nama orang lain atau menempatkan orang lain menggantikan individu dalam ujian.

2. Kecurangan akademik dalam situasi di luar kelas atau saat mengerjakan penugasan dari dosena dalah sebagai berikut.

a. Menyalin bahan dari sumber lain tanpa sepengetahuan penulis.

b. Menyajikan data palsu.

c. Mengijinkan karyanya dijiplak orang lain.

d. Mereka-reka suatu referensi atau bibliografi.

e. Menyalin bahan untuk karya tulis dari buku atau terbitan lain tanpa mencantumkan sumbernya.

f. Mengubah data penelitian.

g. Menjiplak karya tulis mahasiswa lain dengan sepengetahuan pemilik.

h. Memastikan keberadaan buku, jurnal atau artikel lain dalam perpustakaan dengan penempatan yang tidak benar dan dilakukan dengan sengaja sehingga mahasiswa lain tidak 
dapat menemukannya. Selain itu, sengaja memotong atau menggunting artikel atau bab yang dibutuhkan.

i. Pada situasi di mana mahasiswa saling menilai hasil karyanya satu sama lain, mengadakan persetujuan dengan seseorang atau beberapa mahasiswa untuk memberi nilai melebihi yang seharusnya.

j. Menyerahkan karya tulis sebagai suatu karya individual padahal karya tersebut dikerjakan bersama-sama dengan mahasiswa lain.

k. Mengerjakan suatu karya tulis bagi orang lain.

1. Berbohong mengenai kondisi medis atau hal lain untuk memperoleh kelonggaran waktu penyerahan tugas atau bahkan dibebaskan dari kewajiban untuk mengerjakan tugas.

$\mathrm{m}$. Menjiplak karya tulis mahasiswa lain tanpa sepengetahuan pemilik.

n. Membeli karya tulis yang sengaja dijual pihak lain.

o. Mencoba memperoleh pertimbangan khusus dengan menawarkan atau menyampaikan perlakuan tertentu seperti menyuap, merayu, atau korupsi.

Sementara itu, menurut Anderman (2007) indikator perilaku saat melakukan kecurangan akademik berikut ini.

1. Melakukan kecurangan dalam mengerjakan tugas atau pekerjaan rumah.

2. Menggunakan kertas contekan ketika menghadapi ujian.

3. Menyalin jawaban dari orang lain atau teman saat mengerjakan ujian.

4. Ketika tidak memahami tugas sekolah, siswa mendapatkan jawaban dari teman.

5. Menyalin jawaban siswa lain saat mengerjakan tugas sekolah.

\section{Faktor-faktor yang mempengaruhi kecurangan akademik}

Timbulnya kecurangan dalam bidang akademik dapat dikaitkan dengan beragam faktor, baik faktor internal maupun faktor eksternal individu. Faktorfaktor yang dapat mendorong timbulnya kecurangan akademik adalah faktor demografi, individual, dan situasional (Robinson et.al., 2004). Berikut penjabaran dari ketiga faktor tersebut.

1. Faktor demografi, seperti: usia, jenis kelamin, tingkatan kelas/angkatan, IPK. McCabe dan Trevino (1997, dalam Clement, 2001) juga menemukan kecurangan akademik dipengaruhi oleh usia dan IPK.
2. Faktor individual yang mendorong timbulnya kecurangan akademik seperti: keyakinan yang rendah akan kemampuan dalam hal akademik (self-efficacy academic), takut akan kegagalan, keinginan untuk berprestasi, harga diri, moralitas, dan nilai yang dimiliki. Menurut Whitley (1998, dalam Clement, 2001), hal-hal yang terkait dengan kecurangan akademik yang berasal dari faktor individual adalah harapan untuk sukses, pernah/ tidak pernah mencontek di masa lalu, usaha belajar yang tidak memadai, dan bersikap positif terhadap kecurangan akademik.

3. Faktor situasional yang mendorong timbulnya kecurangan akademik yaitu: pengawasan yang kurang saat ujian berlangsung atau rendahnya kontrol pengajar atau institusi pendidikan terhadap timbulnya kecurangan akademik. Selain itu juga terdapat faktor situasional yang lain, seperti: bentuk dan tingkat kesulitan tes, penekanan pada pencapaian nilai dan peringkat bukan pada pemahaman, group code, dan keberhasilan atau kegagalan sebelumnya. Menurut Whitley (dalam Clement, 2001), adanya dukungan dari pihak lain untuk melakukannya, dan imbalan/reward yang diperoleh jika berhasil memperoleh nilai yang baik. Menurut McCabe dan Trevino (dalam Clement, 2001) faktor kontekstual yang dapat mempengaruhi timbulnya kecurangan akademik adalah: mendapat celaan jika nilai yang diperoleh buruk, menjadi anggota pada suatu kelompok/gank mahasiswa, dan merasa akan menerima hukuman yang berat jika mendapat nilai buruk.

\section{Akibat Kecurangan Akademik}

Kecurangan dalam bidang akademik dapat menyebabkan dampak negatif bagi individu pelakunya dan juga bagi institusi pendidikan yang terkait. Integritas/kejujuran akademik seharusnya menjadi perhatian serius oleh pihak pendidik, siswa/ mahasiswa, bahkan masyarakat umum (Bushweller, 1999; Wilson, 1999, dalam Mason, 2006). Bagi pihak pendidik, kecurangan akademik yang dilakukan oleh mahasiswa menyebabkan proses dan hasil pendidikan menjadi tidak valid. Mahasiswa yang melakukan kecurangan juga membuat pihak mahasiswa yang memiliki integritas akademik menjadi rugi, seperti saat proses seleksi kesempatan kerja setelah menyelesaikan pendidikan di universitas (Bushweller, 1999, dalam Mason, 2006). Indeks prestasi yang dimiliki oleh mahasiswa pelaku kecurangan akademik tidak valid walaupun nilainya tinggi. Bagi institusi pendidikan, perilaku kecurangan akademik dapat menyebabkan menurunnya kualifikasi standar pendidikan pada 
institusi tersebut di tengah-tengah institusi pendidikan lainnya. Stakeholder menjadi tidak mempercayai kredibilitas institusi pendidikan tersebut.

Berdasarkan beragam tinjauan pustaka tersebut, peneliti merumuskan perilaku kecurangan sebagai tindakan curang yang dilakukan untuk mencapai tujuan tertentu, seperti nilai ujian yang tinggi. Penelitian ini akan mengungkap faktor-faktor penyebab terjadinya perilaku kecurangan akademik terutama saat ujian yang ditinjau dari faktor individual, faktor demografi, dan faktor situasional, serta temuan lainnya.

Dinamika Psikologis Pelaku Kecurangan Akademik

Menurut Wright (2004), pada pelaku kecurangan akademik terjadi ketidak-konsistenan antara keyakinan (bahwa kecurangan akademik adalah sesuatu yang salah) dengan perilaku yang ditunjukkan. Pelaku meyakini bahwa tindakan mereka salah tetapi tetap melakukannya. Jika dilihat dari teori cognitive dissonance oleh Leon Festinger (1957, dalam Walgito, 2002) bahwa kondisi di mana mahasiswa pelaku kecurangan akademik mengalami ambivalensi atau ketidakpastian apakah perilaku kecurangan akademik itu benar-benar salah pada saat melakukannya. Menurut Festinger, dalam suatu kondisi tertentu sikap itu biasanya konsisten satu dengan yang lain, dan dalam tindakan atau perilaku juga konsisten satu dengan yang lain. Misalnya, jika seseorang berpendapat bahwa perilaku kecurangan akademik adalah suatu yang salah maka semestinya tindakan atau perilakunya juga konsisten dengan sikapnya tersebut. Namun jika terjadi inkonsistensi atau ketidakkonsistenan maka terjadi dissonansi. Dinamika kebutuhan untuk mengurangi dissonansi cukup relevan jika dikaitkan dengan terjadinya perilaku kecurangan akademik (Wright, 2004). Sebagian besar mahasiswa yang menjadi subyek penelitian oleh Wright mengakui bahwa mereka termasuk orang-orang yang menjunjung etika dan moral. Tetapi di sisi lain, pada perilaku nyatanya, mereka melakukan kecurangan akademik. Kesimpulan dari penelitian tersebut adalah terjadi ketidakseimbangan antara sikap mereka dengan perilaku nyata yang dilakukan. Apalagi menurut mereka, dengan melakukan kecurangan akademik maka akan diperoleh keuntungan yang cukup signifikan seperti: 'saya akan memperoleh peringkat yang lebih baik' atau dengan alasan'tidak seorangpun yang pernah ketahuan mencontek'.

Dalam penelitian ini akan ditinjau bagaimana dinamika psikologis pelaku kecurangan akademik jika dilihat dari teori cognitive dissonance oleh Festinger (1957, dalam Walgito, 2002) dan bagaimana justifikasi serta rasionalisasi yang digunakan oleh pelaku kecurangan akademik seperti pada penelitian yang dilakukan oleh Wrigth (2004).

\section{METODOLOGI PENELITIAN}

Metode yang digunakan dalam penelitian ini adalah metode kualitatif. Melalui metode kualitatif dapat dipahami situasi sosial yang menjadi fokus penelitian secara holistik, kompleks, dan dinamis. Pada akhirnya dapat dilakukan analisis situasi sosial secara mendalam.

Subjek dalam penelitian ini adalah tiga orang mahasiswa suatu LPTK dan masih aktif mengikuti perkuliahan. Secara lebih rinci, karakteristik yang ditetapkan bagi subjek adalah: mahasiswa yang berasal dari salah satu angkatan 2005-2008, lakilaki atau perempuan. Subjek yang dipilih untuk diwawancarai lebih lanjut adalah berdasarkan hasil rekomendasi dari pengajar di kelas tersebut atau dari teman sekelasnya.

\section{Prosedur Pelaksanaan}

Subjek dipilih berdasarkan informasi dan rekomendasi dari pengajar di kelas tersebut atau dari teman sekelasnya. Setelah subjek ditentukan, maka dilakukan pendekatan yang dilanjutkan wawancara dengan menggunakan pedoman wawancara yang memuat pokok-pokok pertanyaan sesuai tujuan penelitian. Berikut penjelasan lebih rinci tentang persiapan penelitian.

a. Peneliti meminta informasi dan rekomendasi dari pengajar atau pihak mahasiswa lain yang sekelas dengan subjek tentang mahasiswa yang cenderung melakukan kecurangan akademik.

b. Peneliti menyusun pedoman wawancara yang memuat pokok-pokok pertanyaan untuk menjawab permasalahan penelitian. Pedoman wawancara yang disusun bersifat pedoman umum yang memuat topik-topik yang akan ditanyakan.

d. Selain pedoman wawancara, penelitijuga menyusun lembar catatan tentang wawancara yang dilakukan. Lembar catatan berisi identitas (biodata) subjek, waktu dan tempat wawancara, durasi wawancara, topik-topik yang telah ditanyakan, topik-topik yang belum ditanyakan atau yang masih membutuhkan penjelasan lebih jauh oleh subjek, masalahmasalah atau catatan khusus tentang wawancara, hasil observasi terhadap subjek saat wawancara dilaksanakan, serta tindak lanjut wawancara bila diperlukan.

Metode yang digunakan untuk mengumpulkan data pada penelitian ini adalah metode wawancara. Metode wawancara digunakan untuk menjawab 
permasalahan penelitian: faktor-faktor apa saja yang berperan dalam melakukan kecurangan akademik dan bagaimana dinamika psikologis pelaku saat sebelum, sedang, dan setelah melakukan kecurangan akademik. Wawancara yang dilakukan menggunakan konsep wawancara semiterstruktur. Jenis wawancara ini termasuk dalam kategori in-depth interview dan bertujuan untuk menemukan permasalahan secara lebih terbuka (Sugiyono, 2007).

Instrumen yang digunakan adalah pedoman wawancara yang digunakan secara langsung oleh peneliti. Pedoman wawancara yang disusun memuat topik-topik umum pertanyaan yang diajukan.

a. Apa saja perilaku kecurangan akademik yang pernah dilakukan?

b. Faktor demografi apa saja yang berperan dalam melakukan kecurangan akademik?

c. Faktor individual apa saja yang berperan dalam melakukan kecurangan akademik?

d. Faktor situasional apa saja yang berperan dalam melakukan kecurangan akademik?

e. Bagaimana dinamika psikologis pelaku saat sebelum, sedang, dan setelah melakukan kecurangan akademik?

Pertanyaanlapanganyang digunakan selanjutnya terdiri atas 30 pertanyaan yang terkait dengan kelima pertanyaan umum seperti disebutkan sebelumnya. Berikut adalah jadwal dan lokasi berlangsungnya wawancara terhadap subjek penelitian:

1. Inisial subjek : $\mathrm{R}$

Tempat wawancara : ruang kelas

Waktu wawancara $: 2 \mathrm{kali}$

2. Inisial subjek : $\mathrm{H}$

Tempat wawancara : ruang kelas

Waktu wawancara : 2 kali

3. Inisial subjek : M

Tempat wawancara : ruang kelas

Waktu wawancara : 2 kali

Hasil wawancara ditranskripsikan sehingga diperoleh laporan verbatim untuk dianalisis lebih lanjut. Jika data dianggap belum memadai setelah hasil wawancara pertama diperoleh dan ditranskripsikan, maka peneliti menghubungi subjek kembali untuk menyempurnakan data yang diinginkan. Kemudian data keseluruhan dianalisis sesuai dengan tujuan penelitian ini.

\section{Teknik Analisis Data}

Analisis data kualitatif menurut Miles \& Huberman (dalam Sugiyono, 2007) dilakukan secara interaktif melalui proses reduksi data, display data, dan verifikasi data. Setelah proses wawancara yang didahului dengan proses rapport (pendekatan) maka data yang diperoleh akan dianalisis. Dalam melakukan analisis, peneliti akan memaparkan data tentang gambaran umum subjek penelitian berdasarkan lembar isian yang diisi oleh subjek sebelum wawancara dimulai. Kemudian dengan menggunakan transkrip wawancara secara verbatim, peneliti akan memulai menganalisis tema-tema sesuai tujuan penelitian. Selanjutnya akan dilakukan pembandingan tentang tema-tema yang ditemukan di antara masing-masing subjek penelitian. Pada tahap akhir dilakukan penarikan kesimpulan hasil penelitian.

\section{HASIL DAN PEMBAHASAN}

\section{Analisis Intrasubjek}

Berikut adalah ringkasan hasil observasi dan wawancara yang dilakukan kepada subjek penelitian. Isi tabel berikut merupakan hasil analisis intrasubjek penelitian.

Tabel 1. Persamaan dan Perbedaan Antarsubjek

\begin{tabular}{|c|c|c|c|}
\hline Kategori & $\mathrm{R}$ & $\mathrm{H}$ & M \\
\hline \multicolumn{4}{|l|}{ Usia } \\
\hline Jenis kelamin & Laki-laki & Laki-laki & Perempuan \\
\hline Angkatan & 2007 & 2007 & 2008 \\
\hline $\begin{array}{l}\text { Jenis perilaku } \\
\text { kecurangan } \\
\text { yang } \\
\text { dilakukan }\end{array}$ & $\begin{array}{l}\text { bertanya } \\
\text { kepada teman }\end{array}$ & $\begin{array}{l}\text { bertanya } \\
\text { kepada } \\
\text { teman. } \\
\text { Mencatat } \\
\text { kata kunci } \\
\text { dalam bentuk } \\
\text { contekan }\end{array}$ & $\begin{array}{l}\text { bertanya } \\
\text { kepada teman }\end{array}$ \\
\hline \multicolumn{4}{|l|}{$\begin{array}{l}\text { Faktor } \\
\text { Demografi }\end{array}$} \\
\hline IPK & $\begin{array}{l}\text { memutus- } \\
\text { kan untuk } \\
\text { melakukan } \\
\text { kecurangan } \\
\text { akademik } \\
\text { saat ujian } \\
\text { dikarena- } \\
\text { kan Indeks } \\
\text { Prestasi/ } \\
\text { IP setiap } \\
\text { semester } \\
\text { yang terus } \\
\text { merosot akibat } \\
\text { kesibukan-nya } \\
\text { yang semakin } \\
\text { bertambah } \\
\text { terutama } \\
\text { dalam } \\
\text { menjalan-kan } \\
\text { usahanya. }\end{array}$ & $\begin{array}{l}\text { sejak } \\
\text { semester } \\
2 \text { IP yang } \\
\text { diperoleh } \\
\text { terus } \\
\text { merosot. } \\
\text { Hal ini } \\
\text { dikarena-kan } \\
\text { kesibukan- } \\
\text { nya di } \\
\text { jalur musik } \\
\text { sehingga } \\
\text { mengang- } \\
\text { gu proses } \\
\text { belajarnya }\end{array}$ & $\begin{array}{l}\text { IP yang } \\
\text { dimiliki saat } \\
\text { ini sudah } \\
\text { cukup bagus } \\
\text { sehingga } \\
\text { kalaupun } \\
\text { melakukan } \\
\text { kecurangan } \\
\text { akademik itu } \\
\text { dikarenakan } \\
\text { keinginan } \\
\text { untuk } \\
\text { menjawab } \\
\text { soal yang } \\
\text { kosong. } \\
\text { Tapi bukan } \\
\text { bertujuan } \\
\text { untuk } \\
\text { meningkat- } \\
\text { kan IP secara } \\
\text { langsung. }\end{array}$ \\
\hline $\begin{array}{l}\text { Usia/tingkat } \\
\text { kelas saat } \\
\text { pertama } \\
\text { melakukan } \\
\text { kecurangan } \\
\text { kademik }\end{array}$ & Saat SMA & $\begin{array}{l}\text { Saat SMP dan } \\
\text { SMA }\end{array}$ & Saat SMA \\
\hline
\end{tabular}




\begin{tabular}{|c|c|c|c|}
\hline $\begin{array}{l}\text { Faktor } \\
\text { Individual }\end{array}$ & & & \\
\hline $\begin{array}{l}\text { Keyakinan } \\
\text { diri yang } \\
\text { rendah akan } \\
\text { keberha-silan } \\
\text { dalam ujian }\end{array}$ & cukup yakin & $\begin{array}{l}\text { yakin dengan } \\
\text { keberha- } \\
\text { silannya } \\
\text { dalam ujian } \\
\text { mata kuliah } \\
\text { yang disukai }\end{array}$ & $\begin{array}{l}\text { yakin akan } \\
\text { keberhasil- } \\
\text { annya dalam } \\
\text { ujian }\end{array}$ \\
\hline $\begin{array}{l}\text { Takut akan } \\
\text { kegagalan }\end{array}$ & $\begin{array}{l}\text { merasa harus } \\
\text { 'memperta- } \\
\text { hankan' } \\
\text { nilainya } \\
\text { yang bagus } \\
\text { meskipun } \\
\text { tidak memiliki } \\
\text { persiapan. }\end{array}$ & $\begin{array}{l}\text { H merasa } \\
\text { tidak takut } \\
\text { untuk gagal, } \\
\text { karena } \\
\text { penilaian } \\
\text { bukan hanya } \\
\text { berasal dari } \\
\text { nilai ujian. H } \\
\text { melakukan } \\
\text { kecurangan } \\
\text { karena } \\
\text { mengingin- } \\
\text { kan nilai } \\
\text { yang lebih } \\
\text { bagus. }\end{array}$ & $\begin{array}{l}\text { merasa } \\
\text { takut jika } \\
\text { nilainya jelek } \\
\text { sementara } \\
\text { teman-teman } \\
\text { yang lain } \\
\text { berusaha } \\
\text { mencapai } \\
\text { nilai bagus } \\
\text { dengan } \\
\text { melakukan } \\
\text { kecurangan. } \\
\text { Akhirnya } \\
\text { ikut juga } \\
\text { melakukan } \\
\text { kecurangan }\end{array}$ \\
\hline $\begin{array}{l}\text { Keinginan } \\
\text { untuk } \\
\text { berprestasi }\end{array}$ & $\begin{array}{l}\text { merasa } \\
\text { butuh untuk } \\
\text { memperoleh } \\
\text { nilai yang } \\
\text { tinggi }\end{array}$ & $\begin{array}{l}\text { H merasa } \\
\text { tidak ingin } \\
\text { terlihat } \\
\text { berprestasi } \\
\text { tetapi } \\
\text { dari hasil } \\
\text { kecurang-an. }\end{array}$ & $\begin{array}{l}\text { perilaku } \\
\text { kecurangan } \\
\text { yang } \\
\text { dilakukan } \\
\text { bukan karena } \\
\text { keinginan } \\
\text { untuk } \\
\text { berprestasi. }\end{array}$ \\
\hline Kategori & $\mathrm{R}$ & $\mathrm{H}$ & $\mathrm{M}$ \\
\hline $\begin{array}{l}\text { Moralitas } \\
\text { dan nilai } \\
\text { yang dimiliki }\end{array}$ & $\begin{array}{l}\text { penanaman } \\
\text { nilai-nilai } \\
\text { kejujuran oleh } \\
\text { orangtua }\end{array}$ & $\begin{array}{l}\text { selama ini } \\
\text { orangtua } \\
\text { menanam- } \\
\text { kan kejujuran } \\
\text { kepada } \\
\text { dirinya }\end{array}$ & $\begin{array}{l}\text { orang tuanya } \\
\text { menanam- } \\
\text { kan kejujuran } \\
\text { melalui } \\
\text { perbuatan, } \\
\text { bukan dengan } \\
\text { perkataan } \\
\end{array}$ \\
\hline $\begin{array}{l}\text { Usaha belajar } \\
\text { yang tidak } \\
\text { memadai }\end{array}$ & $\begin{array}{l}\text { - jarang } \\
\text { belajar, } \\
\text { hanya } \\
\text { mengan- } \\
\text { dalkan } \\
\text { materi yang } \\
\text { pernah } \\
\text { diberikan } \\
\text { dosen di } \\
\text { kelas } \\
\text { - merasa tidak } \\
\text { maksimal } \\
\text { dalam } \\
\text { belajar }\end{array}$ & $\begin{array}{l}\text { H merasa } \\
\text { belum } \\
\text { maksimal } \\
\text { belajar selama } \\
\text { ini. }\end{array}$ & $\begin{array}{l}\text { usaha untuk } \\
\text { belajar } \\
\text { yang tidak } \\
\text { memadai } \\
\text { mendorong } \\
\text { terjadinya } \\
\text { perilaku } \\
\text { kecurangan }\end{array}$ \\
\hline $\begin{array}{l}\text { Bersikap } \\
\text { positif } \\
\text { terhadap } \\
\text { kecurangan } \\
\text { akademik }\end{array}$ & $\begin{array}{l}\text { merasa tidak } \\
\text { ada masalah } \\
\text { jika mahasiswa } \\
\text { melakukan } \\
\text { kecurangan } \\
\text { karena untuk } \\
\text { memperoleh } \\
\text { nilai yang } \\
\text { bagus. }\end{array}$ & $\begin{array}{l}\text { jika hanya } \\
\text { ingin lulus } \\
\text { maka perilaku } \\
\text { kecurangan } \\
\text { tidak menjadi } \\
\text { suatu yang } \\
\text { negatif. } \\
\text { Namun, } \\
\text { jika ingin } \\
\text { berprestasi } \\
\text { tetapi dengan } \\
\text { melakukan } \\
\text { kecurangan } \\
\text { maka hal itu } \\
\text { membuat H } \\
\text { menyikapi } \\
\text { perilaku }\end{array}$ & $\begin{array}{l}\text { perilaku } \\
\text { kecurangan } \\
\text { sebagai sesuatu } \\
\text { yang tidak } \\
\text { baik bahkan } \\
\text { mengang- } \\
\text { gapnya sebagai } \\
\text { sesuatu yang } \\
\text { membodohi diri } \\
\text { sendiri. }\end{array}$ \\
\hline
\end{tabular}

\begin{tabular}{|c|c|c|c|}
\hline & & $\begin{array}{l}\text { kecurangan } \\
\text { sebagai sesuatu } \\
\text { yang negatif. }\end{array}$ & \\
\hline \multicolumn{4}{|l|}{$\begin{array}{l}\text { Faktor } \\
\text { Situasional } \\
\end{array}$} \\
\hline $\begin{array}{l}\text { Rendahnya } \\
\text { pengawas- } \\
\text { an/kontrol }\end{array}$ & $\begin{array}{l}\text { - dosen tidak } \\
\text { memberla- } \\
\text { kukan }\end{array}$ & $\begin{array}{l}\text { pengawasan } \\
\text { yang tidak } \\
\text { ketat }\end{array}$ & $\begin{array}{l}\text { - penga- } \\
\text { wasan ujian } \\
\text { yang tidak }\end{array}$ \\
\hline $\begin{array}{l}\text { pengajar } \\
\text { dan institusi } \\
\text { pendidikan } \\
\text { terhadap } \\
\text { perilaku } \\
\text { kecurangan } \\
\text { akademik }\end{array}$ & $\begin{array}{l}\text { aturan yang } \\
\text { jelas dalam } \\
\text { menyikapi } \\
\text { perilaku } \\
\text { kecurangan } \\
\text { mahasiswa, } \\
\text { hanya } \\
\text { sekedar } \\
\text { himbauan }\end{array}$ & $\begin{array}{l}\text { dan jumlah } \\
\text { mahasiswa } \\
\text { dalam satu } \\
\text { kelas yang } \\
\text { terlalu penuh. }\end{array}$ & $\begin{array}{l}\text { ketat sangat } \\
\text { memung- } \\
\text { kinkan bagi } \\
\text { mahasiswa } \\
\text { untuk } \\
\text { melaku-kan } \\
\text { kecurang-an } \\
\text { - belum ada } \\
\text { peraturan } \\
\text { yang dieks- } \\
\text { plisitkan } \\
\text { tentang } \\
\text { sanksi bagi } \\
\text { pelaku } \\
\text { kecurang-an }\end{array}$ \\
\hline $\begin{array}{l}\text { Bentuk } \\
\text { dan tingkat } \\
\text { kesulitan tes }\end{array}$ & $\begin{array}{l}\text { - dilihat dari } \\
\text { bentuk soal } \\
\text { maka R lebih } \\
\text { memilih } \\
\text { memakai } \\
\text { jawaban } \\
\text { sendiri } \\
\text { dalam soal } \\
\text { pilihan } \\
\text { ganda. } \\
\text { Namun } \\
\text { dalam soal } \\
\text { essay, R } \\
\text { memper- } \\
\text { timbang-kan } \\
\text { jawaban } \\
\text { yang } \\
\text { diberikan } \\
\text { teman saat } \\
\text { ditanya } \\
\text { - merasa } \\
\text { lebih sulit } \\
\text { mengha-dapi } \\
\text { soal yang } \\
\text { menuntut } \\
\text { hapalan }\end{array}$ & $\begin{array}{l}\text { berbentuk } \\
\text { essay dan } \\
\text { membutuh- } \\
\text { kan hapalan }\end{array}$ & $\begin{array}{l}\text { Kesiapan } \\
\text { menghadapi } \\
\text { ujian dan } \\
\text { bentuk } \\
\text { soal essay } \\
\text { terkadang } \\
\text { membuat } \\
\text { M bertanya } \\
\text { kepada } \\
\text { teman akan } \\
\text { jawabannya }\end{array}$ \\
\hline Kategori & $\mathrm{R}$ & $\mathrm{H}$ & M \\
\hline $\begin{array}{l}\text { Penekanan } \\
\text { pada } \\
\text { pencapaian } \\
\text { nilai dan } \\
\text { peringkat }\end{array}$ & $\begin{array}{l}\text { merasa ada } \\
\text { sebagian } \\
\text { dosen yang } \\
\text { menekankan } \\
\text { pada } \\
\text { pencapaian } \\
\text { nilai, sehingga } \\
\text { jika sudah } \\
\text { tidak bisa } \\
\text { menjawab soal } \\
\text { maka bertanya } \\
\text { kepada teman. }\end{array}$ & $\begin{array}{l}\text { kebanyak- } \\
\text { an dosen } \\
\text { menekan- } \\
\text { kan pada } \\
\text { pencapaian } \\
\text { nilai ujian }\end{array}$ & $\begin{array}{l}\text { merasa } \\
\text { penting untuk } \\
\text { mencapai nilai } \\
\text { yang bagus } \\
\text { apalagi jika } \\
\text { berada dalam } \\
\text { situasi di } \\
\text { mana teman- } \\
\text { temannya } \\
\text { melakukan } \\
\text { kecurangan }\end{array}$ \\
\hline Group code & $\begin{array}{l}\text {-teman-teman } \\
\text { di kelasnya } \\
\text { memiliki } \\
\text { 'kesepakan' } \\
\text { untuk saling } \\
\text { menutupi } \\
\text { kekurangan } \\
\text { dengan } \\
\text { melakukan } \\
\text { kecurangan }\end{array}$ & $\begin{array}{l}\text {-teman-teman } \\
\text { sekelasnya } \\
\text { mengang-gap } \\
\text { wajar tentang } \\
\text { perilaku } \\
\text { kecurang- } \\
\text { an, asalkan } \\
\text { tidak semua } \\
\text { jawaban soal } \\
\text { adalah hasil }\end{array}$ & $\begin{array}{l}\text { - teman-teman } \\
\text { berpendapat } \\
\text { melakukan } \\
\text { kecurangan } \\
\text { saat ujian } \\
\text { adalah hal } \\
\text { yang wajar, } \\
\text { sudah biasa, } \\
\text { tidak malu- } \\
\text { malu lagi. }\end{array}$ \\
\hline
\end{tabular}




\begin{tabular}{|c|c|c|c|}
\hline & $\begin{array}{l}\text { - tidak ada } \\
\text { mahasiswa } \\
\text { yang melapor- } \\
\text { kannya } \\
\text { kepada dosen }\end{array}$ & kecurangan & $\begin{array}{l}\text { - Belum ada } \\
\text { mahasiswa } \\
\text { yang lapor ke } \\
\text { dosen. }\end{array}$ \\
\hline $\begin{array}{l}\text { Dukungan } \\
\text { dari pihak }\end{array}$ & $\begin{array}{l}\text { mahasiswa } \\
\text { saling }\end{array}$ & $\begin{array}{l}\text { merasa } \\
\text { didukung }\end{array}$ & $\begin{array}{l}\text { menganggap } \\
\text { teman- }\end{array}$ \\
\hline lain & $\begin{array}{l}\text { mendukung } \\
\text { dan bekerja } \\
\text { sama dalam } \\
\text { melakukan } \\
\text { kecurangan } \\
\text { sehingga } \\
\text { terjadi } \\
\text { juga saling } \\
\text { menutupi } \\
\text { kekurangan } \\
\text { satu sama lain }\end{array}$ & $\begin{array}{l}\text { teman- } \\
\text { temannya, } \\
\text { bahkan } \\
\text { didorong } \\
\text { untuk } \\
\text { bertanya } \\
\text { kepada } \\
\text { beberapa } \\
\text { teman sampai } \\
\text { jawaban } \\
\text { diperoleh. }\end{array}$ & $\begin{array}{l}\text { temannya } \\
\text { cukup } \\
\text { mendukung } \\
\text { terjadinya } \\
\text { perilaku } \\
\text { kecurangan } \\
\text { karena jika } \\
\text { M bertanya } \\
\text { kepada } \\
\text { temannya, } \\
\text { maka akan } \\
\text { dijawab. Jika } \\
\text { memang tidak } \\
\text { mendukung } \\
\text { mestinya } \\
\text { temannya itu } \\
\text { tidak akan } \\
\text { memberi } \\
\text { jawaban }\end{array}$ \\
\hline $\begin{array}{l}\text { Reward dan } \\
\text { punishment } \\
\text { terkait } \\
\text { pencapaian } \\
\text { suatu nilai } \\
\text { hasil ujian }\end{array}$ & $\begin{array}{l}\text { - merasa } \\
\text { percaya } \\
\text { diri jika } \\
\text { nilai yang } \\
\text { diperoleh } \\
\text { tidak buruk. } \\
\text { - jika nilai } \\
\text { yang } \\
\text { diperoleh } \\
\text { buruk } \\
\text { maka akan } \\
\text { tersingkir } \\
\text { dari } \\
\text { pergaulan. }\end{array}$ & $\begin{array}{l}\text { - perasaan } \\
\text { senang } \\
\text { karena } \\
\text { dipuji oleh } \\
\text { teman dan } \\
\text { keluarga. } \\
\text { - tidak } \\
\text { merasa } \\
\text { memper- } \\
\text { oleh punish- } \\
\text { ment jika } \\
\text { nilai buruk. }\end{array}$ & $\begin{array}{l}\text { - merasa } \\
\text { senang jika } \\
\text { nilai yang } \\
\text { diperoleh } \\
\text { bagus tapi } \\
\text { bukan } \\
\text { dari hasil } \\
\text { melakukan } \\
\text { kecurangan } \\
\text { - jika } \\
\text { memperoleh } \\
\text { nilai yang } \\
\text { buruk maka } \\
\text { merasa tidak } \\
\text { malu karena } \\
\text { biasanya } \\
\text { masih ada } \\
\text { temannya } \\
\text { yang } \\
\text { memperoleh } \\
\text { nilai lebih } \\
\text { buruk. }\end{array}$ \\
\hline Kategori & $\mathrm{R}$ & $\mathrm{H}$ & M \\
\hline $\begin{array}{l}\text { Dinamika } \\
\text { Psikologis }\end{array}$ & $\begin{array}{l}\text { awalnya } \\
\text { merasa malu, } \\
\text { kemudian } \\
\text { saat bertanya } \\
\text { merasa } \\
\text { mengganggu } \\
\text { teman, dan } \\
\text { setelahnya } \\
\text { tidak serta } \\
\text { merta senang } \\
\text { karena } \\
\text { merasa bukan } \\
\text { jawaban } \\
\text { sendiri. Ada } \\
\text { rasa bersalah } \\
\text { dan menyesal. }\end{array}$ & $\begin{array}{l}\text { awalnya } \\
\text { merasa } \\
\text { deg-degan } \\
\text { karena takut } \\
\text { ketahuan. } \\
\text { Kemudian } \\
\text { saat bertanya } \\
\text { merasa yakin } \\
\text { akan diberi } \\
\text { jawaban } \\
\text { memasti- } \\
\text { kannya } \\
\text { dengan } \\
\text { bertanya } \\
\text { kepada teman } \\
\text { yang lain } \\
\text { lagi. Setelah } \\
\text { ujian selesai, } \\
\text { merasa } \\
\text { bersalah } \\
\text { karena tidak } \\
\text { belajar }\end{array}$ & $\begin{array}{l}\text { awalnya } \\
\text { merasa } \\
\text { bingung } \\
\text { dan takut } \\
\text { ketahuan. } \\
\text { Kemudian } \\
\text { saat bertanya } \\
\text { merasa } \\
\text { senang, takut, } \\
\text { dan bingung } \\
\text { (senang } \\
\text { karena dapat } \\
\text { bocoran } \\
\text { jawaban, } \\
\text { takut karena } \\
\text { kalau } \\
\text { ketahuan ada } \\
\text { resikonya, } \\
\text { bingung } \\
\text { karena merasa } \\
\text { dilematis } \\
\text { apakah tetap }\end{array}$ \\
\hline
\end{tabular}

\begin{tabular}{|c|c|c|c|}
\hline & & $\begin{array}{l}\text { maksimal } \\
\text { dan bertanya- } \\
\text { tanya } \\
\text { tentang nilai } \\
\text { yang akan } \\
\text { diperoleh. }\end{array}$ & $\begin{array}{l}\text { melakukan } \\
\text { kecurangan } \\
\text { atau tidak). } \\
\text { Setelahnya, } \\
\text { merasa biasa } \\
\text { saja walaupun } \\
\text { ada rasa } \\
\text { bersalah } \\
\text { karena tidak } \\
\text { belajar dan } \\
\text { tidak yakin } \\
\text { pada diri } \\
\text { sendiri. }\end{array}$ \\
\hline $\begin{array}{l}\text { Pendapat } \\
\text { subjek terkait } \\
\text { dengan } \\
\text { perilaku } \\
\text { kecurangan } \\
\text { di dunia } \\
\text { kerja }\end{array}$ & $\begin{array}{l}\text { "Itu sudah } \\
\text { hukum alam } \\
\text { sendiri... kita } \\
\text { harus menjaga } \\
\text { kita sendiri... } \\
\text { pasti peluang } \\
\text { itu ada... } \\
\text { bagaimana } \\
\text { cara } \\
\text { menjaganya } \\
\text { saja..." }\end{array}$ & $\begin{array}{l}\text { "Kadang- } \\
\text { kadang saya } \\
\text { ga suka juga } \\
\text { lihat orang } \\
\text { nyontek, } \\
\text { mungkin } \\
\text { saya marah.. } \\
\text { atau mungkin } \\
\text { saya kasih } \\
\text { dulu mereka } \\
\text { latihan, } \\
\text { persiapan. } \\
\text { Kalau udah } \\
\text { siap, baru } \\
\text { saya kasih } \\
\text { ujian..." }\end{array}$ & $\begin{array}{l}\text { "Mungkin } \\
\text { saya akan } \\
\text { menjelas- } \\
\text { kan... dikasih } \\
\text { pengertian sih } \\
\text { bu... kita ubah } \\
\text { sistemnya } \\
\text {...jadi ga } \\
\text { penting yang } \\
\text { nilai harus } \\
\text { bagus... tapi } \\
\text { ga ngerti... } \\
\text { Meskipun } \\
\text { nilai jelek } \\
\text { tapi kita } \\
\text { ngerti...jangan } \\
\text { ngejar nilai } \\
\text { maksudnya } \\
\text { kejar ilmu tapi } \\
\text { jangan kejar } \\
\text { nilai berapa } \\
\text { yang harus } \\
\text { dapat..." }\end{array}$ \\
\hline
\end{tabular}

\section{Analisis Antarsubjek}

\section{Persamaan Antarsubjek}

Berdasarkan analisis data yang dilakukan terhadap hasil wawancara, terlihat bahwa ketiga subjek memilih jenis perilaku kecurangan akademik saat ujian dengan bertanya kepada teman walaupun subjek $\mathrm{H}$ terkadang membuat contekan yang berisi kata-kata kunci dari materi kuliah.

Berdasarkan faktor individual, sepertinya perilaku kecurangan yang dilakukan oleh ketiga subjek bukan karena keyakinan diri yang rendah akan keberhasilan dalam ujian. Ketiga subjek merasa yakin akan keberhasilannya dalam ujian. Terkait dengan moralitas dan nilai yang dimiliki, ketiga subjek dididik untuk memiliki kejujuran. Ketiga subjek melakukan kecurangan karena merasa tidak maksimal dalam belajar.

Terkait dengan faktor situasional yang mempengaruhi timbulnya perilaku kecurangan adalah pengawasan yang tidak maksimal dari dosen/ pengawas ujian dan belum adanya aturan yang jelas dari institusi tentang hukuman terhadap pelaku kecurangan. Terkait dengan bentuk soal, ketiga subjek melakukan kecurangan jika soal yang disajikan berbentuk essay dan tidak mengetahui jawabannya. Ketiga subjek berpendapat bahwa teman-teman 
sekelas mendukung terjadinya perilaku kecurangan dan menganggap wajar jika dilakukan. Selain itu tidak ada mahasiswa yang melaporkan perilaku kecurangan kepada dosen. Kondisi ini cukup berperan pada diri ketiga subjek untuk melakukan kecurangan.

Ketiga subjek mengalami dissonansi kognitif terkait dengan perilaku kecurangan yang dilakukan. Terjadi ketidakseimbangan antara pikiran, perasaan, dan perbuatan saat melakukan kecurangan di waktu ujian. Kondisi yang dialami seperti: malu, takut, bingung, cemas dialami saat melakukan kecurangan. Kemudian setelahnya, ketiga subjek merasa bersalah dan menyesal karena melakukan kecurangan.

\section{Perbedaan Antarsubjek}

Berdasarkan faktor demografi, subjek $\mathrm{R}$ dan $M$ melakukan kecurangan sejak duduk di bangku SMA. Sementara H sejak duduk di bangku SMP. Jika dikaitkan dengan IPK, subjek $\mathrm{R}$ dan $\mathrm{H}$ merasa perlu untuk memperoleh nilai bagus walaupun dengan melakukan kecurangan karena IPK yang diperoleh terus merosot akibat kesibukan di bidang lain. Sementara M merasa bahwa perilaku kecurangan yang dilakukan bukan untuk meningkatkan IPK secara langsung namun keinginan untuk menjawab soal yang masih kosong.

Terkait dengan faktor individual, subjek $\mathrm{H}$ merasa tidak takut untuk gagal dalam ujian, sementara itu subjek $R$ merasa takut jika nilai yang sudah cukup bagus sebelumnya menjadi buruk sehingga mendorongnya untuk melakukan kecurangan. Subjek M melakukan kecurangan karena takut nilai yang diperoleh buruk dan ternyata teman-temannya memperoleh nilai bagus dengan melakukan kecurangan. Subjek R merasa butuh untuk memperoleh nilai/prestasi sehingga melakukan kecurangan. Sementara subjek $\mathrm{H}$ dan $\mathrm{M}$ merasa tidak ingin memperoleh prestasi tinggi dikarenakan perilaku kecurangan. Demikian juga dengan harga diri, subjek R melakukan kecurangan akademik agar memiliki harga diri di antara teman-temannya karena nilai yang tidak buruk. Sementara subjek H dan M melakukan kecurangan untuk memperoleh nilai yang bagus adalah bukan untuk merasa dihargai di antara teman-temannya.

Dalam menyikapi perilaku kecurangan, ketiga subjek memiliki sikap yang berbeda: subjek $\mathrm{R}$ merasa tidak ada masalah jika mahasiswa melakukan kecurangan karena agar nilai yang diperoleh bagus. Subjek H menyikapi perilaku kecurangan tergantung dari tujuannya, jika hanya ingin lulus maka perilaku kecurangan menurutnya positif. Namun jika ingin berprestasi tapi dengan melakukan kecurangan maka hal ini menurutnya negatif. Sementara itu, subjek $M$ menganggap perilaku kecurangan sebagai sesuatu yang negatif.

Berdasarkan faktor situasional, subjek $\mathrm{R}$ dan $\mathrm{H}$ melakukan kecurangan karena merasa sebagian dosen menekankan pada pencapaian nilai yang bagus dalam ujian. Sementara subjek M merasa terpacu untuk memperoleh nilai bagus dengan melakukan kecuranganjika ternyata teman-temannya memperoleh nilai yang bagus namun dengan kecurangan. Selama ini, subjek R merasa percaya diri jika memperoleh nilai bagus walaupun dengan cara melakukan kecurangan. Sementara jika nilai yang diperoleh buruk, subjek $R$ merasa 'tersingkir' dari pergaulan dengan temantemannya. Subjek H merasa senang mendapat pujian dari teman-temannya jika memperoleh nilai bagus namun juga tidak merasa akan diejek teman-temannya jika memperoleh nilai buruk. Sementara itu, subjek $\mathrm{M}$ juga merasa senang jika memperoleh nilai bagus namun juga tidak merasa malu jika memperoleh nilai buruk karena biasanya masih ada nilai temannya yang lebih buruk.

Terkait dengan pendapat subjekjika menghadapi perilaku kecurangan di dunia pekerjaan, subjek $\mathrm{R}$ berpendapat hal tersebut sebagai suatu yang berpeluang untuk terjadi sehingga diperlukan antisipasi diri saja. Sementara itu, subjek $\mathrm{H}$ dan $\mathrm{M}$ merasa tidak setuju dengan perilaku kecurangan jika dikaitkan dengan dunia pekerjaan di bidang pendidikan.

\section{Diskusi}

Sehubungan dengan jenis perilaku kecurangan yang dilakukan saat ujian, bertanya kepada teman untuk meminta jawaban adalah yang paling dominan terjadi. Jika dilihat dari pendapat Newstead, FranklyStokes, dan Armsted (1996, dalam Haryanto, 1998) perilaku seperti itu termasuk dalam kategori kecurangan akademik saat ujian berlangsung yaitu kolusi yang terencana antara dua atau lebih mahasiswa untuk mengkomunikasikan jawabannya selama ujian berlangsung.

Hasil lainnya yang diperoleh dalam penelitian ini yaitu bahwa ketiga subjek melakukan kecurangan akademik sejak sebelum duduk di perguruan tinggi yaitu di bangku SMP atau SMA, namun bukan sejak di SD. Tuntutan keberhasilan akademik pada usia kanakkanak tidak sebesar tuntutan keberhasilan akademik pada masa perkembangan selanjutnya termasuk masa dewasa. Selain itu, perilaku kecurangan cenderung lebih banyak terjadi pada tingkat sekolah menengah dibandingkan tingkat sekolah dasar karena pengajaran yang lebih fokus pada pencapaian peringkat dan 
kemampuan (Anderman \& Midgley, 2004; Anderman \& Turner, 2004). Perilaku kecurangan dilakukan karena perolehan IPK yang tidak memadai, sehingga timbul beragam usaha untuk menaikkannya termasuk melakukan kecurangan. Berdasarkan pendapat para peneliti sebelumnya, perilaku kecurangan dipengaruhi oleh faktor demografi seperti: usia, jenis kelamin, tingkatan kelas/angkatan, dan IPK. Namun dalam penelitian ini yang terbukti berpengaruh adalah usia, kelas/angkatan dalam hal ini terkait dengan saat mulai melakukan kecurangan (saat di bangku sekolah menengah), dan IPK.

Faktor individual yang mendorong timbulnya perilaku kecurangan seperti: keyakinan yang rendah akan kemampuan dalam hal akademik (academic self-efficacy), takut akan kegagalan, keinginan untuk berprestasi, harga diri, moralitas, dan nilai yang dimiliki (Robinson et.al., 2004). Menurut Whitley (1998, dalam Clement, 2001), hal-hal yang terkait dengan perilaku kecurangan akademik yang berasal dari faktor individual adalah harapan untuk sukses, pernah/tidak pernah mencontek di masa lalu, usaha belajar yang tidak memadai, bersikap positif terhadap kecurangan akademik. Dalam penelitian ini, temuan yang diperoleh adalah bahwa faktor individual yang memperngaruhi timbulnya perilaku kecurangan: takut akan kegagalan dan usaha belajar yang tidak memadai. Temuan lain tentang hal ini adalah bahwa ada subjek yang merasa takut gagal jika ternyata teman-temanya terlihat berhasil namun dengan cara melakukan kecurangan. Akhirnya subjek melakukan kecurangan juga. Seandainya kondisi teman-temannya tidak demikian atau sistem yang digunakan memang tidak memberikan peluang terhadap timbulnya perilaku kecurangan, maka subjek merasa tidak takut jika mendapat nilai buruk dan tidak akan melakukan kecurangan.

Faktor situasional yang mendorong timbulnya perilaku kecurangan dalam penelitian ini adalah: pengawasan yang kurang saat ujian berlangsung atau rendahnya kontrol pengajar atau institusi pendidikan terhadap timbulnya perilaku kecurangan. Selain itu juga terdapat faktor situasi yang lain, seperti: bentuk dan tingkat kesulitan tes, penekanan pada pencapaian nilai dan peringkat bukan pada pemahaman, group code, dan keberhasilan atau kegagalan sebelumnya (Robinson, et.al. 2004). Menurut Whitley (dalam Clement, 2001), adanya dukungan dari pihak lain untuk melakukannya, dan imbalan/reward yang diperoleh jika berhasil memperoleh nilai yang baik. Menurut McCabe dan Trevino (dalam Clement, 2001) faktor kontekstual yang dapat mempengaruhi timbulnya perilaku kecurangan adalah: mendapat celaan (jika nilai yang diperoleh buruk), menjadi anggota pada suatu kelompok/gank mahasiswa, dan merasa akan menerima hukuman yang berat jika mendapat nilai buruk.

Sementara itu, faktor situasional yang mempengaruhi timbulnya perilaku kecurangan berdasarkan hasil penelitian ini adalah:

- rendahnya pengawasan dan kontrol institusi terhadap perilaku kecurangan

- soal yang berbentuk essay dan membutuhkan hapalan

- penekanan pada pencapaian nilai dan peringkat

- group code

- dukungan dari pihak lain

Selama ini, sistem dan aturan yang jelas terkait dengan perilaku kecurangan dinilai belum memadai, sehingga mungkin sekali jika ada pembenahan sistem dan aturan itu maka perilaku kecurangan akan dapat diminimalkan. Pemberian sanksi yang jelas terbukti akan mengurangi terjadinya perilaku kecurangan. Informasi yang diperoleh dari salah seorang staf pengajar di salah satu universitas menggambarkan hal itu. Sanksi yang diberikan di tempat tersebut adalah dengan memberlakukan skors (dilarang kuliah) selama satu semester ke depan dan menghanguskan semua nilai yang dilakukan pada semester saat terjadinya perilaku kecurangan. Kondisi ini, menurutnya, terbukti efektif mengurangi terjadinya kecurangan akademik.

Terkait dengan bentuk soal, essay dinilai lebih membuat terjadinya perilaku kecurangan karena tidak ada 'clue' di dalam soal. Pelaku merasa membutuhkan suatu 'clue' atau petunjuk berupa minimal kata kunci sehingga akan dapat menjawab soal. Selain itu, bentuk soal yang membutuhkan hapalan juga ternyata lebih mendorong terjadinya perilaku kecurangan. Semestinya soal yang disajikan kepada mahasiswa di perguruan tinggi bukan yang mengandalkan hapalan karena proses berpikir mahasiswa yang sudah lebih kompleks. Sebaiknya soal yang disajikan adalah soal yang membutuhkan proses berpikir yang lebih tinggi seperti aplikasi, analisis, sintesis, atau evaluasi. Dalam teori Bloom, tingkatan ini dikenal dengan tingkatan kognitif mulai tingkat ketiga dan seterusnya ke yang lebih tinggi.

Terjadinya perilaku kecurangan diakibatkan juga oleh penekanan pada pencapaian nilai dan peringkat, bukan pada proses belajar. Sistem evaluasi yang baik adalah yang mengikutsertakan aspek proses pembelajaran sebagai bagian dari penilaian. Jika kondisi ini yang terjadi maka kemungkinan perilaku 
kecurangan akan dapat dikurangi karena mahasiswa memahami bahwa ada aspek penilaian lain yang digunakan selain nilai ujian.

Group code yang terjadi adalah sebagian besar mahasiswa menganggap perilaku kecurangan sebagai sesuatu yang wajar dan saling menutupi terjadinya perilaku kecurangan tersebut sehingga tidak ada mahasiswa yang melaporkannya kepada pihak dosen. Kondisi ini cukup memprihatinkan karena terlihat bahwa perilaku kecurangan dijustifikasi sebagai suatu bagian dari proses pencapaian nilai. Selain itu terlihat adanya faktor konformitas di antara mahasiswa untuk melakukan kecurangan. Mahasiswa yang sebelumnya tidak melakukan maka dapat saja menjadi turut melakukan kecurangan akademik.

Perilaku kecurangan juga dipengaruhi dengan adanya dukungan dari pihak lain dan dalam penelitian ini pihak lain yang dimaksud adalah teman-teman sekelas. Bahkan ada yang mengajak untuk melakukan kecurangan agar mendapat nilai yang bagus. Evaluasi mahasiswa oleh dosen yang menekankan pada perolehan nilai akhir kemungkinan menjadi penyebab terjadinya saling dukung di antara mahasiswa dalam melakukan kecurangan.

Terkait dengan dinamika psikologis mahasiswa pelaku kecurangan akademik, terbukti bahwa terjadi dissonansi yaitu ketidak-konsistenan antara keyakinan (bahwa kecurangan akademik adalah sesuatu yang salah) dengan perilaku yang ditunjukkan. Pelaku meyakini bahwa tindakan kecurangan itu salah tapi tetap melakukannya. Temuan yang diperoleh menunjukkan bahwa di dalam diri pelaku kecurangan akademik terjadi beragam kondisi: malu dan cemas atau takut ketahuan saat akan melakukan, merasa senang saat memperoleh contekan jawaban dari teman, dan merasa bersalah atau menyesal setelah melakukannya. Namun sepertinya tidak ada langkah kongkrit untuk berusaha meninggalkan perilaku kecurangan di masa berikutnya. Menurut Wright (2004), pada pelaku kecurangan terjadi ketidakkonsistenan antara keyakinan (bahwa kecurangan akademik adalah sesuatu yang salah) dengan perilaku yang ditunjukkan. Pelaku meyakini bahwa tindakan mereka salah tapi tetap melakukannya. Kondisi ini sejalan dengan teori cognitive dissonance oleh Leon Festinger (1957, dalam Walgito, 2002) bahwa kondisi di mana mahasiswa pelaku kecurangan akademik mengalami ambivalensi atau ketidakpastian apakah perilaku kecurangan itu benar-benar salah pada saat mereka melakukannya. Menurut Festinger, dalam suatu kondisi tertentu sikap itu biasanya konsisten satu dengan yang lain, dan dalam tindakan atau perilaku juga konsisten satu dengan yang lain. Misalnya, jika seseorang berpendapat bahwa perilaku kecurangan akademik adalah suatu yang salah maka semestinya tindakan atau perilakunya juga konsisten dengan sikapnya tersebut. Namun jika terjadi inkonsistensi atau ketidakkonsistenan maka terjadi dissonansi. Jika ini yang terjadi maka seseorang itu akan mengurangi dissonansi untuk mencapai keseimbangan. Dalam hal perilaku kecurangan akademik, yang terjadi adalah pelaku berusaha memandang perilaku itu sebagai sesuatu yang 'wajar' sehingga terjadi rasionalisasi untuk membenarkan perilaku itu. Selain itu, kemungkinan yang terjadi adalah individu akan menghindari meningkatnya dissonansi, misalnya dengan mengubah perilaku, mengubah lingkungan, atau menambah elemen baru.

Dinamika kebutuhan untuk mengurangi dissonansi cukup relevan jika dikaitkan dengan temuan dinamika psikologis pelaku kecurangan akademik dalam penelitian ini. Menurut Wright (2004), sebagian besar mahasiswa yang menjadi subjek penelitiannya mengakui bahwa mereka termasuk orang-orang yang menjunjung etika dan moral. Tetapi di sisi lain, pada perilaku nyatanya, mereka melakukan kecurangan akademik. Demikian juga dalam penelitian ini, subjek mengaku memperoleh pendidikan moral, dalam hal ini kejujuran, dari pihak keluarga sejak kecil yang membuat mereka menjunjung nilai kejujuran. Namun sepertinya nilai kejujuran yang dimiliki tidak berlaku saat mereka melakukan kecurangan akademik.

Wright (2004) mengidentifikasi beberapa justifikasi atau rasionalisasi yang digunakan mahasiswa untuk mengurangi dissonansi yang dialami sehingga malah termotivasi untuk melakukan kecurangan akademik. Jenis rasionalisasi yang digunakan seperti penolakan bahwa kecurangan akan merugikan pihak lain ('perilaku saya tidak merugikan orang lain'), penolakan tentang tanggung jawab personal ('dosen tidak terlalu peduli terhadap mahasiswa'), penolakan adanya resiko personal ('tidak ada yang pernah ketahuan'), moralitas selektif ('saya adalah orang yang jujur, tetapi saya harus mencontek dalam kondisi ini'), serta memandang kecurangan sebagai sesuatu yang diterima oleh norma sosial ('sekarang ini, semua mahasiswa mencontek'). Sementara dalam penelitian ini, justifikasi atau rasionalisasi yang ditemukan dan digunakan adalah moralitas selektif ('saya adalah orang yang jujur, tetapi saya harus mencontek dalam kondisi ini'), memandang kecurangan sebagai sesuatu yang diterima oleh norma sosial ('sekarang ini, semua mahasiswa mencontek').

Jika dikaitkan dengan dunia pekerjaan, Becker 
et.al. (2006) berpendapat bahwa mahasiswa yang cenderung melakukan ketidakjujuran dalam bidang akademik maka akan cenderung melakukan beragam ketidakjujuran di dunia pekerjaan. Dalam penelitian ini, pendapat subjek cenderung menolak terjadinya perilaku kecurangan di dunia pekerjaan terutama jika dikaitkan dengan peran sebagai guru nantinya. Jika kondisi ini yang terjadi maka perilaku kecurangan sepertinya tidak akan dilakukan saat berada di dunia pekerjaan. Namun kekonsistenan antara pendapat sekarang dengan perilaku di masa yang akan datang perlu dibuktikan dengan penelitian jangka panjang (longitudinal) sehingga dapat diketahui apakah memang pendapat Becker tersebut juga terjadi pada mahasiswa yang menjadi subjek penelitian ini.

\section{Saran}

Berdasarkan proses dan hasil penelitian yang diperoleh, maka dikemukakan saran-saran sebagai berikut:

1. Penelitian perlu dilakukan dengan menambah jumlah dan variasi subjek sehingga diperoleh hasil yang lebih komprehensif dan luas.

2. Penelitian ini mempunyai fokus pada perilaku kecurangan akademik saat melakukan ujian. Oleh karena itu, perlu dilakukan penelitian lanjutan tentang perilaku kecurangan akademik saat melakukan tugas-tugas akademik selain ujian di kelas.

3. Penelitian ini dapat dikembangkan dengan menggunakan pendekatan kuantitatif sehingga diperoleh juga gambaran dari jumlah subjek yang cukup besar.

4. Data dalam penelitian ini dapat diperkaya dengan melakukan wawancara terhadap pihak dosen dan pengambil keputusan/pimpinan pada institusi terkait.

5. Berdasarkan hasil penelitian terlihat perlunya pembenahan sistem ujian, sistem evaluasi mahasiswa dan peraturan yang diberlakukan dalam mengantisipasi perilaku kecurangan akademik di kalangan mahasiswa.

\section{PENUTUP}

\section{Kesimpulan}

Terdapat beberapa faktor dan subfaktor yang membuat terjadinya perilaku kecurangan akademik. Berdasarkan hasil analisis terlihat bahwa:

1. terkait dengan faktor demografi, dua dari tiga subjek memilih melakukan kecurangan karena indeks prestasi yang terus menurun. Dua dari tiga subjek juga melakukan kecurangan akademik sejak duduk di bangku SMA;
2. terkait dengan faktor individual, terjadinya perilaku kecurangan pada minimal dua dari tiga subjek disebabkan oleh takut akan kegagalan dan usaha belajar yang tidak memadai;

3. terkait dengan faktor situasional, perilaku kecurangan dilakukan karena:

- rendahnya pengawasan dan kontrol institusi terhadap perilaku kecurangan

- soal yang berbentuk essay dan membutuhkan hapalan

- penekanan pada pencapaian nilai dan peringkat - group code

- dukungan dari pihak lain (teman-teman); dan

4. pelaku kecurangan mengalami dinamika psikologis yang menunjukkan terjadinya dissonansi yaitu ketidakkonsistenan antara keyakinan (bahwa kecurangan akademik adalah sesuatu yang salah) dengan perilaku yang ditunjukkan. Pelaku meyakini bahwa tindakan kecurangan salah tapi tetap melakukannya.

\section{DAFTAR PUSTAKA}

Alhadza, A. (2002). Masalah menyontek / cheating di dunia pendidikan. Jurnal pendidikan dan kebudayaan Vol. 038. th. 8

Anderman, E.M., Murdock T.B. (editors). (2007). Academic cheating.

Angell, L.R. (2006). The relationship of impulsiveness, personal efficacy, and academic motivation to college cheating. College Student Journal, Vol.40(1), p.118-131

Clement, M.J. (2001). Academic dishonesty: to be or not to $b e$ ? Journal of Criminal Justice Education: 12:2. p.253-270

Elias, R.Z. (2008). Anti intellectual attitudes and academic self efficacy among business students. Journal of Education for Business. Vol.84:2. p.110-116

Haryanto, M. (1998). Hubungan tingkah laku curang dalam ujian dengan nilai (value) yang dianut mahasiswa pada tiga fakultas di Universitas Indonesia (skripsi, tidak diterbitkan).

Mason,K. (2006) Student integrity. The Business Review. Vol.6:1. p.297-300

Robinson, E. Amburgey, R. Swank, E. Faulker, C. (2004). Test cheating in rural college: Studying the importance and situational factors. College Student Journal: 38,3. p.380-395

Sugiyono. (2007). Metode penelitian pendidikan:pendekatan kuantitatif, kualitatif, dan RED. Bandung: Alfabeta.

Walgito, B. (2002). Psikologi sosial: Suatu pengantar. Yogyakarta: Andi Offset. 
Faktor yang Berperan...

Wolfolk, A. (2004). Educational psychology. NJ: PrenticeHall Inc.

Wright, T.A. 2004. When a student blows the whistle (on Himself): A personal experience essays on 'delayed' integrity in a classroom setting. Journal of Management Inquiry. 13;4. p.289-303

\section{KETERANGAN PENULIS}

Anna Armeini, dilahirkan di Padangsidempuan, Mei 1976. Saat ini aktif sebagai dosen Psikologi Pendidikan FIP UNJ 